\title{
Marketing Organic Vegetables in Yogyakarta: Consumers Behavior in Modern Retailers and Community Market
}

\author{
Dyah Ismoyowati ${ }^{*}, 1$ \\ ${ }^{1}$ Department of Agro-industrial Technology, Faculty of Agricultural Technology \\ Universitas Gadjah Mada, Jl. Flora No.1 Bulaksumur 55281, Indonesia. \\ Email: dyah_ismoyowati@ugm.ac.id*
}

\begin{abstract}
People's awareness of their health can be seen with the more and more popular of organic produce including vegetables. Display existed in modern retailers show the rising demand in Yogyakarta. Changing way of how people's buying from regular to organic ones was influenced by usage of online social media. It is interesting to see how marketing innovation has been done to build customers community using social media by organic and healthy food producers in a community market.
\end{abstract}

Keywords: Behavior, community, market, organic, vegetables.

\section{INTRODUCTION}

Since the last few decades, the awareness of today's society on agriculture, health and the global environment has increased through government and other campaigns of the importance of healthier eating and lifestyle (Griffith (2010) in Suharjo (2013)).

Agricultural products are important in human consumption. Modern retailers as well as traditional market provide these human basic needs. This paper focus in vegetables consumption especially the organic ones because higher quality of the products demand was growing in Yogyakarta.

Sulaeman (2007) defined organic food as "a food which comes from organic farming system that apply practical management with the aim to preserve ecosystem to achieve sustainable production and controlling weed, pest and disease through various way such as recycling the residues of plants and livestock, selection and crop rotation, management of irrigation, cultivation and planting as well as the use of biological materials".

Modern retailers are important outlets for higher quality of vegetables including the organic ones. Nonetheless, in this area just like in Indonesia in general, traditional market still considered dominant in supplying people's vegetables consumption. Suharjo (2013) study in Jakarta and Bogor area revealed that there was barrier to purchasing organic food product included that it was hard to find organic products in traditional market. To be more specific about organic vegetables, ordinary traditional market rarely provides organic vegetables, but there emerged a community market for organic vegetables in Yogyakarta. The term of community market was used because this market related to specific community, in this case community of organic and healthy products sellers and buyers. Several characteristics of the community market suit this phenomenon since it provides direct interaction between consumers and local producers; done in a traditional way, not a selfservice one; there is personal interaction between seller and buyer; taken place in a rather open/outdoor space, not permanent, has its simple display, specifically scheduled, and operating in a short period of time. Traditional market in Java used to be operating only in its "dina pasaran", either once a week, once every five days, or once every 35 days. So, the community market is an updated form of traditional market to fit modern people's behavior in their new way of shopping and socializing.

This paper aimed to provide characteristics of the organic vegetables consumers, and attempt to describing the consumers' behavior in organic vegetables consumption both in modern retailer and community market in Yogyakarta. 


\section{METHODS}

This research have been done in eight outlets of modern retailers and three outlets of community markets in Yogyakarta. The data and information collected through observation, interviews and survey to 210 respondent consumers in both channels. Descriptive statistics, correlations and regression were done to capture consumer behaviors in this area.

\section{RESULTS AND DISCUSSION}

The study revealed that organic vegetables consumers from both channels, modern retailers and community markets are significantly indifference in term of their characteristics. Consumers of organic vegetables dominated by women shoppers (83.3\%) in its younger age of 30-40 years old (58.6\%) who had their high education (Bachelor and more) as shown in Table 1.

In Indonesia, generally about 50\% of people's income goes to food (BPS, 2014). In this finding, among the respondent consumers, $10 \%$ of its spending goes to organic vegetables. The frequency of organic vegetables buying was 4-6 times per month for $43.3 \%$ of the consumers. $39 \%$ of them have their buying more than 6 times and only17.7\% less than 4 times a month. This is considerably rational since vegetables must be consumed within days to get its freshness.

People shifted to organic vegetables consumption mostly because they want to have a healthy life (81.4\%). In consuming organic vegetables, the consumers $(93.3 \%)$ mostly shopped in modern retailers, but it was interesting to know that from the same consumer respondents, some of them also went to community market (42.4\%).

They chose modern retailers because they were interested in the quality of the products (44.4\%), location (26.0\%), and the products fits their needs (17.3\%); while consumers that chose the community market mainly because they were interested in doing direct buying from the local farmers (39.3\%), influenced by friends and family (21.3\%), and the products suit their needs (16.9\%).

Both consumers of modern outlets (84.2\%) as well as community market (66.3\%) got their information about organic vegetables mainly from friends and families in their decision making to buy organic vegetables; but it was also noted that the online social media only affected consumers of community market (25.8\%). This means that community building that had been done by producers of community market relatively succeeded. This is considerably in line with the findings of Atmadi (2013) that also found that in Jakarta, similar community had its website to create awareness and perception of organic products for a healthier life.

Table 1. Characteristics of the Respondents

\begin{tabular}{|c|c|}
\hline Characteristics & Percentage \\
\hline Gender & $\begin{array}{l}\text { Man (16.7\%), Woman } \\
(83.3 \%)\end{array}$ \\
\hline Age & $\begin{array}{l}30-40 \text { Years }(58.6 \%), 41-50 \\
\text { Years }(25.7 \%),>50 \text { Years } \\
(15.7 \%)\end{array}$ \\
\hline Occupation & $\begin{array}{l}\text { Student (0\%), Self- } \\
\text { Employed (19\%), Civil } \\
\text { Servants (33.8\%), Private } \\
\text { Employees (31\%), } \\
\text { Housewives (16.2\%) }\end{array}$ \\
\hline Education & $\begin{array}{l}\text { Diploma (5.2\%), Bachelor's } \\
\text { (84.8\%), Post-Graduate } \\
(10 \%)\end{array}$ \\
\hline District area & $\begin{array}{l}\text { Yogyakarta (53.3\%), } \\
\text { Sleman }(46.7 \%)\end{array}$ \\
\hline $\begin{array}{l}\text { Frequency of } \\
\text { consuming } \\
\text { organic } \\
\text { vegetables in } \\
\text { one month }\end{array}$ & $\begin{array}{l}\text { 1-3 Times }(17.6 \%), 4-6 \\
\text { Times (43.3\%), } 7-9 \text { Times } \\
(28.1 \%), 10 \text { Times Or More } \\
(11 \%)\end{array}$ \\
\hline $\begin{array}{l}\text { Monthly } \\
\text { Income }\end{array}$ & $\begin{array}{l}\text { Rp 3,000,000 (23.8\%), Rp } \\
\text { 3,000,001-Rp 5,000,000 } \\
\text { (42.9\%), Rp 5,000,001-Rp } \\
\text { 7,000,000 (25.7\%), Rp } \\
\text { 7,000,001-Rp 10,000,000 } \\
(3.3 \%),>\text { Rp 10,000,000 } \\
(4.3 \%)\end{array}$ \\
\hline $\begin{array}{l}\text { Monthly } \\
\text { spending on } \\
\text { organic } \\
\text { vegetables }\end{array}$ & $\begin{array}{l}<\text { Rp 250,000 (16.2\%), Rp } \\
\text { 150,000-Rp 250,000 } \\
\text { (37.6\%), Rp 250,001- } \\
\text { Rp350,000 (24.3\%), Rp } \\
\text { 350,001-Rp 450,000 } \\
(17.6 \%),>\operatorname{Rp} 450,000 \\
(4.3 \%)\end{array}$ \\
\hline
\end{tabular}

Both producers in modern retailers and community markets provided online selling and delivery services, but the study revealed 
that only $11.0 \%$ of them experienced the online transaction. It was also found out that the consumers revealed to be happy experiencing physically choosing and buying organic vegetables rather than order it online.

Consumer behavior was attempted to be analyzed in a regression model of buyer's purchasing decision as a function of marketing mix strategy i.e. 4Ps. The model met the tests as follows. The normality test can be seen in the following histogram which forms a normal distribution pattern meaning that normal assumption was met.

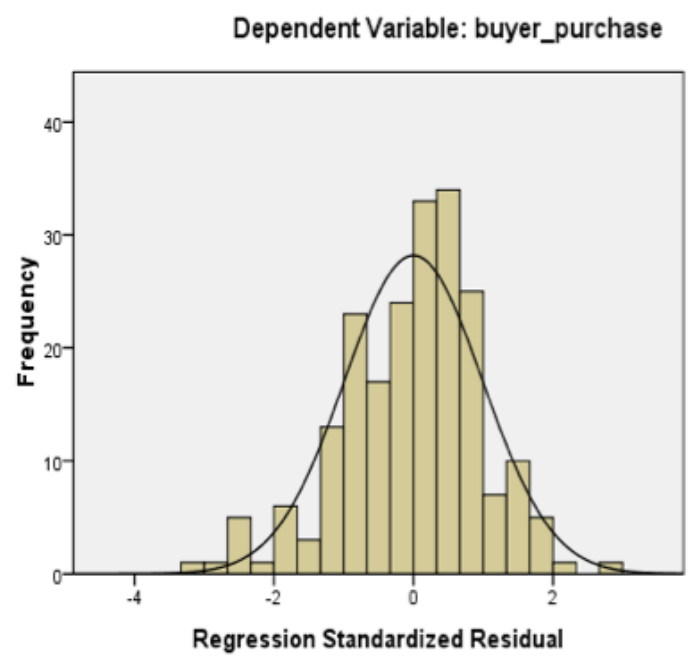

Figure 1. The histogram

Residual normality test used Kolmogorov -Smirnov turned out that the normal assumption had been also met $(0.286>0.05)$. Autocorrelation test was done with a run test and resulted that the significance value was greater than $0.05(0.679>0.05)$ indicating that the data used were not autocorrelated. Based on the result of the following scatterplot, it was no heteroscedasticity. The test also done using Park test method which resulted in the significance value generated from variables of product, price, place and promotion that had a value greater than 0.05 , meaning that in the data used there was no heteroscedasticity.

Based on the results of the independent variables had Tolerance value $>0.1$ and $\mathrm{VIF}<10$ indicating that in the independent variables there were no multicollinearity. Other than that, the independent variables had linearity value less than $0.05(0.000$ $<0.05$ ), so this value indicated that all independent variables met the assumption of linearity.

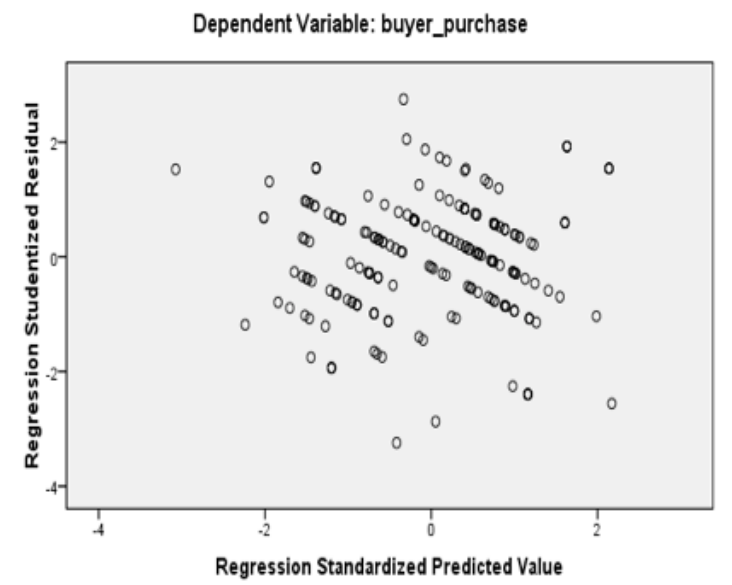

Figure 2. The scatterplot

The significant value of $\mathrm{F}$ test was smaller than 0.05 significance level, so the linear regression model which was estimated, all the independent variables i.e. product, price, place, and promotion were simultaneously explaining the dependent variable of buyer's purchase decision. Result of $t$ test of the independent variables exhibited that there were two significant variables of marketing mix in the model i.e. product and price. But, the marketing mix variables of place and promotion, were not significant at the confidence level of 95\%. Table 2 presented the coefficients of the regression.

Table 2. Coefficients of Regresion

\begin{tabular}{|c|c|c|c|}
\hline \multirow[t]{2}{*}{ Model } & \multicolumn{3}{|c|}{ Unstandardized Coefficients } \\
\hline & B & \multicolumn{2}{|c|}{ Std. Error } \\
\hline (Constant) & -.600 & \multicolumn{2}{|l|}{1.014} \\
\hline Product & .282 & \multicolumn{2}{|l|}{.050} \\
\hline Price & .304 & \multicolumn{2}{|l|}{.114} \\
\hline Place & .042 & \multicolumn{2}{|l|}{.112} \\
\hline Promotion & .096 & \multicolumn{2}{|l|}{.093} \\
\hline \multirow[t]{2}{*}{ Model } & $\begin{array}{l}\text { Standardized } \\
\text { Coefficients }\end{array}$ & \multirow[b]{2}{*}{$\mathrm{t}$} & \multirow[b]{2}{*}{ Sig. } \\
\hline & Beta & & \\
\hline (Constant) & & -.591 & .555 \\
\hline Product & .434 & 5.633 & .000 \\
\hline Price & .187 & 2.674 & .008 \\
\hline Place & .027 & .371 & .711 \\
\hline Promotion & .063 & 1.037 & .301 \\
\hline
\end{tabular}

Regarding the decision to buy that affected by marketing mix, the regression result shows that organic vegetables 
consumers in Yogyakarta only significantly affected by product and price matters. This brought about the modern outlets having its advantage in its products, but the community market having its advantage in term of prices. The community market system has its strength in pricing because it allows farmers to get higher prices compare to prices they get when supplying modern retailers; but at the same time consumers can benefit lower prices compare to modern outlets can offer.

The consumers agreed that their consumption of organic vegetables based on the product quality, function, better taste, free of unhealthy chemical matter, organic certified, and overall satisfying. Aside from product mix, they also agreed that the prices of organic vegetables were worth the product qualities.

\section{CONCLUSIONS}

Consumers of organic vegetables can be considered as a smart segment in the society; they are well educated, young and employed. It was found out that mostly women who do the shopping. For this organic vegetables shopping, consumers' experiences in physically choosing the product is important.

Modern retailers still supplied most of the demand, but it was good for consumers of organic vegetables in Yogyakarta to have an alternative outlets to do their shopping in a community market which also fulfilled their interest in directly supporting and interacting with local producers. It is also worthily noted the use of internet, social media in community market development.

\section{ACKNOWLEDGEMENT}

The paper is part of bigger research in organic vegetables agroindustry and its marketing done through the support from RKAT of Faculty of Agricultural Technology, Universitas Gadjah Mada. The author also appreciates TOM (Tani Organik Merapi) and POJOG (Pasar Organik Jogja) for the cooperation.

\section{REFERENCES}

Atmadi, Gayatri. 2013. The Utility of New Media for Organic Community of Indonesia. The Asian Conference on
Media and Mass Communication 2013.

Conference Proceeding.

BPS. 2014. Statistics of Indonesia. Jakarta, BPS Indonesia.

Engel, et al. 1990. Consumer Behaviour. The Dryden Press. Florida.

Suharjo, B., Ahmady, M., and Ahmady, R.M. 2013. Indonesian Consumer's Attitudes towards Organic Products. Proceedings of 8th Asian Business Research Conference 12 April 2013, Bangkok, Thailand.

Sulaeman, A. 2007. Prospek Pasar dan Kiat Pemasaran Produk Organik. Bogor Agriculture University. 